\title{
Alcohol intake and colorectal cancer: a pooled analysis of 8 cohort studies
}

Citation for published version (APA):

Cho, E., Smith-Warner, S. A., Ritz, J., van den Brandt, P. A., Colditz, G. A., Folsom, A. R., Freudenheim, J. L., Giovannucci, E., Goldbohm, R. A., Graham, S., Holmberg, L., Kim, D. H., Malila, N., Miller, A. B., Pietinen, P., Rohan, T. E., Sellers, T. A., Speizer, F. E., Willett, W. C., ... Hunter, D. J. (2004). Alcohol intake and colorectal cancer: a pooled analysis of 8 cohort studies. Annals of Internal Medicine, 140(8), 603-613. https://doi.org/10.7326/0003-4819-140-8-200404200-00007

Document status and date:

Published: 01/01/2004

DOI:

10.7326/0003-4819-140-8-200404200-00007

Document Version:

Publisher's PDF, also known as Version of record

\section{Please check the document version of this publication:}

- A submitted manuscript is the version of the article upon submission and before peer-review. There can be important differences between the submitted version and the official published version of record.

People interested in the research are advised to contact the author for the final version of the publication, or visit the DOI to the publisher's website.

- The final author version and the galley proof are versions of the publication after peer review.

- The final published version features the final layout of the paper including the volume, issue and page numbers.

Link to publication

\footnotetext{
General rights rights.

- You may freely distribute the URL identifying the publication in the public portal. please follow below link for the End User Agreement:

www.umlib.nl/taverne-license

Take down policy

If you believe that this document breaches copyright please contact us at:

repository@maastrichtuniversity.nl

providing details and we will investigate your claim.
}

Copyright and moral rights for the publications made accessible in the public portal are retained by the authors and/or other copyright owners and it is a condition of accessing publications that users recognise and abide by the legal requirements associated with these

- Users may download and print one copy of any publication from the public portal for the purpose of private study or research.

- You may not further distribute the material or use it for any profit-making activity or commercial gain

If the publication is distributed under the terms of Article $25 \mathrm{fa}$ of the Dutch Copyright Act, indicated by the "Taverne" license above, 


\section{Alcohol Intake and Colorectal Cancer: A Pooled Analysis of 8 Cohort Studies}

Eunyoung Cho, ScD; Stephanie A. Smith-Warner, PhD; John Ritz, PhD; Piet A. van den Brandt, PhD; Graham A. Colditz, MD, DrPh; Aaron R. Folsom, MD; Jo L. Freudenheim, PhD; Edward Giovannucci, MD; R. Alexandra Goldbohm, PhD; Saxon Graham, PhD; Lars Holmberg, MD, PhD; Dong-Hyun Kim, MD, PhD; Nea Malila, MD; Anthony B. Miller, MB, BCh; Pirjo Pietinen, DSc; Thomas E. Rohan, MB, BS; Thomas A. Sellers, PhD; Frank E. Speizer, MD; Walter C. Willett, MD; Alicja Wolk, DrMedSci; and David J. Hunter, MB, BS

Background: Epidemiologic studies have generally reported positive associations between alcohol consumption and risk for colorectal cancer. However, findings related to specific alcoholic beverages or different anatomic sites in the large bowel have been inconsistent.

Objective: To examine the relationship of total alcohol intake and intake from specific beverages to the incidence of colorectal cancer and to evaluate whether other potential risk factors modify the association.

Design: Pooled analysis of primary data from 8 cohort studies in 5 countries.

Setting: North America and Europe.

Participants: 489979 women and men with no history of cancer other than nonmelanoma skin cancer at baseline.

Measurements: Alcohol intake was assessed in each study at baseline by using a validated food-frequency questionnaire.

Results: During a maximum of 6 to 16 years of follow-up across the studies, 4687 cases of colorectal cancer were documented. In categorical analyses, increased risk for colorectal cancer was lim- ited to persons with an alcohol intake of $30 \mathrm{~g} / \mathrm{d}$ or greater (approximately $\geq 2$ drinks/d), a consumption level reported by $4 \%$ of women and $13 \%$ of men. Compared with nondrinkers, the pooled multivariate relative risks were $1.16(95 \% \mathrm{Cl}, 0.99$ to 1.36$)$ for persons who consumed 30 to less than $45 \mathrm{~g} / \mathrm{d}$ and $1.41(\mathrm{Cl}, 1.16$ to 1.72 ) for those who consumed $45 \mathrm{~g} / \mathrm{d}$ or greater. No significant heterogeneity by study or sex was observed. The association was evident for cancer of the proximal colon, distal colon, and rectum. No clear difference in relative risks was found among specific alcoholic beverages.

Limitations: The study included only one measure of alcohol consumption at baseline and could not investigate lifetime alcohol consumption, alcohol consumption at younger ages, or changes in alcohol consumption during follow-up. It also could not examine drinking patterns or duration of alcohol use.

Conclusions: A single determination of alcohol intake correlated with a modest relative elevation in colorectal cancer rate, mainly at the highest levels of alcohol intake.

Ann Intern Med. 2004;140:603-613.

www.annals.org

For author affiliations, see end of text.
A lcohol intake is a potentially modifiable behavior that may be related to risk for colorectal cancer (1). Epidemiologic studies on alcohol consumption and risk for colorectal cancer have reported either null or positive associations, with risks that are as much as 5-fold higher among drinkers compared to nondrinkers and with positive associations observed more consistently for rectal than colon cancer (1). Data on risk for cancer at subsites in the colon have been limited. In general, beer intake has been positively related to colorectal cancer, whereas findings for other alcoholic beverages have been inconsistent. Because analyses have varied across studies, it has been difficult to account for discrepancies among studies and in doseresponse relationships.

We evaluated the association between alcohol consumption and the incidence of colorectal cancer, including separate examinations by sex, subsites in the large bowel, and other potential risk factors, by analyzing the primary data from 8 large prospective studies from North America and Europe. Results on alcohol use and occurrence of colorectal cancer have been published for only 4 of these studies; for each, follow-up in our analysis is longer than that in the published analysis (2-5).

\section{Methods}

The Pooling Project of Prospective Studies of Diet and Cancer has been described elsewhere (6). To maximize the quality and comparability of the studies in the project, we formulated general inclusion criteria a priori. For the current analyses, we identified prospective studies (3-5, 7-12) that included at least 50 incident cases of colorectal cancer, assessed long-term dietary intake, had a validation study of the dietary assessment method or a closely related instrument (13-19) (Wolk A. Personal communication), and measured alcohol intake.

The person-time of follow-up in the Nurses' Health Study was divided into 2 segments to take advantage of the more detailed dietary assessment in 1986. In the underlying theory of survival-data analysis, blocks of person-time in different periods are asymptotically uncorrelated, regardless of the extent to which they are derived from the same people (20).

\section{Exclusion Criteria}

We first applied the exclusion criteria for each study, and then excluded participants with implausible energy intakes $\left(>3\right.$ SDs from the study-specific $\log _{\mathrm{e}}$-transformed mean energy intake), no information on alcohol intake, or 
ARTICLE Alcohol Intake and Colorectal Cancer

\section{Context}

Studies suggest that alcohol consumption increases colorectal cancer risk, but the magnitude of the association and its relationship to type of alcoholic beverage and cancer site are ill defined.

\section{Contribution}

This pooled analysis of 8 observational studies showed a small absolute increase in colorectal cancer risk with alcohol consumption of $30 \mathrm{~g} / \mathrm{d}$ or greater (equivalent to 150 $\mathrm{mL}$ of wine), with the greatest risk among people who consumed $45 \mathrm{~g} / \mathrm{d}$ or greater. Risk did not differ by beverage type or for cancer site.

\section{Cautions}

This analysis relied on a single baseline self-report of alcohol consumption.

\section{Implications}

Clinicians should factor the small increased risk for colorectal cancer into discussions with patients about alcohol's risks and benefits.

\section{-The Editors}

a history of cancer other than nonmelanoma skin cancer at baseline.

\section{Case Definition}

Incident colorectal cancers were ascertained in each study by self-report with subsequent medical record review $(3,11)$ or linkage with a cancer registry $(8,21-24)$ or both
(25). Some studies used additional linkage with a death registry $(3,8,11,23-25)$.

\section{Dietary Assessment}

Each study provided data on food, nutrient, and alcohol intake as estimated by a baseline food-frequency questionnaire. All studies but 1 measured usual consumption of individual alcoholic beverages (beer, wine, and liquor); in the New York State Cohort, 1 question on the consumption of alcoholic beverages was asked. The format of the questionnaires varied. Some $(5,9)$ allowed participants to indicate both the frequency of drinking and the usual number of drinks consumed on each occasion; others (3, 4, $11,12)$ had participants choose among categories of total usual consumption. Most of the questionnaires assumed a standard drink size, but the Canadian National Breast Screening Study allowed participants to indicate a different drink size from the standard indicated and the AlphaTocopherol Beta-Carotene Cancer Prevention Study allowed participants to choose from 1 of 3 portion sizes. Each study calculated alcohol intake in grams per day by using the reported frequency of consumption, quantity consumed, and alcohol content of that beverage. For context, in the United States, we assumed that there is $12.8 \mathrm{~g}$ of alcohol in $12 \mathrm{oz}(335 \mathrm{~mL})$ of beer, $10.9 \mathrm{~g}$ in $4 \mathrm{oz}(118$ $\mathrm{mL})$ of wine, and $14.0 \mathrm{~g}$ in $1.5 \mathrm{oz}(44 \mathrm{~mL})$ of 80 -proof liquor (26). Spearman correlation coefficients comparing alcohol intake from the dietary questionnaires used in the studies with diet records or 24-hour dietary recalls generally exceeded 0.7 (Wolk A. Personal communication) (16, 17, 19).

Among dietary covariates, no data on nutrients were

\section{Table 1. Characteristics of the Cohort Studies Included in the Pooled Analysis}

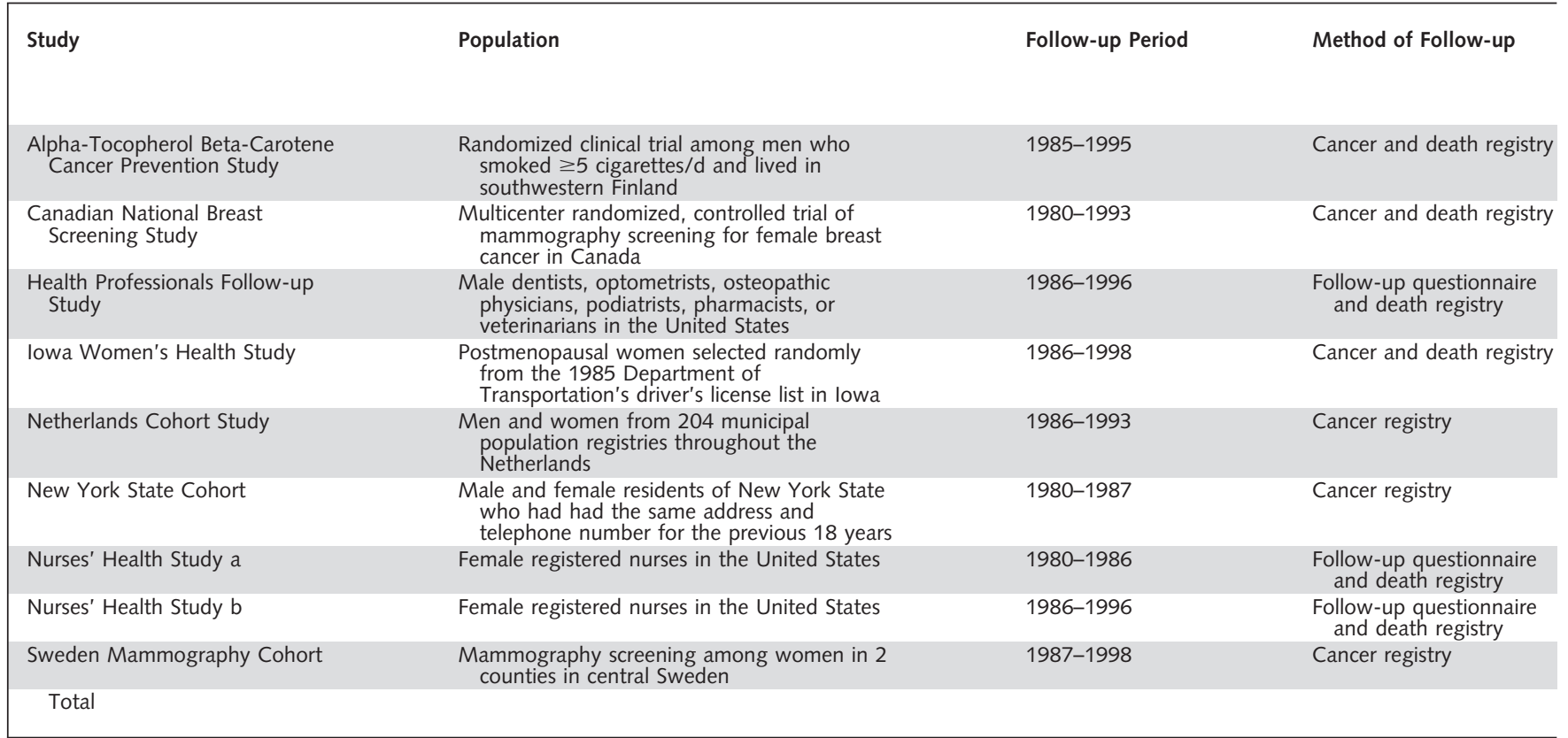

* Cancer outcomes in the New York State Cohort were identified through linkage with a cancer registry; thus, it is difficult to determine the follow-up rate in the cohort.

When a subset of the cohort was followed intensively, loss to follow-up was not related to exposure.

† This value represents a subset of the women included in the Nurses' Health Study a and is not included in the total. 
missing. Intake of red meat and milk was assessed, and fewer than $1 \%$ of values were missing in most studies.

\section{Nondietary Covariates}

Each study collected information on nondietary covariates by using self-administered questionnaires at baseline. Most studies assessed age; smoking habits; physical activity; education; height; body weight; multivitamin use; and, among women, use of oral contraceptives and postmenopausal hormone replacement therapy. The proportion of missing values generally was less than $5 \%$ in each study that measured the covariate. We categorized the covariate information in a consistent manner across studies.

\section{Statistical Analysis}

Alcohol intake was divided into categories by using identical cut-points across the studies. Because the number of cases in higher categories was limited, the cut-point for the highest category was lower in some analyses. To calculate the $P$ value for the test for trend, participants were assigned the median value of their category of alcohol, and this value was used as a continuous variable in the studyspecific regression models.

Each study was analyzed by using the Cox proportional hazards model. Incidence rate ratios were estimated by using SAS PROC PHREG (27) for all studies except the Canadian National Breast Screening Study and the Netherlands Cohort Study, which were analyzed as casecohort studies (28) by using Epicure software (29). For all studies, we stratified participants by age at baseline and the year that the baseline questionnaire was returned. Person- years of follow-up were calculated from the date of return of the baseline questionnaire until the date of diagnosis of colorectal cancer, death, or end of follow-up, whichever came first. We conducted sex-specific analyses; studies that included both sexes were analyzed as two separate cohorts. An indicator variable for missing responses was created for each covariate in a study, if needed. Two-sided 95\% CIs were calculated.

To obtain a single pooled estimate, we used a randomeffects model to combine $\log _{\mathrm{e}}$ relative risks from the individual studies (30). The study-specific relative risks were weighted by the inverse of the sum of their variance and the estimated between-studies variance component. In some studies, no cases were included in the categories of higher alcohol intake and the number of noncases in the corresponding category was very small relative to the sample size. We did not include these studies in the pooled estimates for those categories. We tested for heterogeneity among studies by using the Q statistic $(30,31)$.

We tested whether the associations for alcohol from beer, wine, and liquor differed by using a contrast test of the pooled estimates for each beverage and their covariance matrix from the random-effects model. The test statistic follows approximately a chi-square distribution with 2 degrees of freedom (32).

We tested for variation in relative risks by other potential risk factors by using a meta-regression model (33). We also evaluated associations for subsites of the large bowel and used a Wald test to test the null hypothesis of no difference among the $\log _{\mathrm{e}}$ rate ratios $(32,34)$.

\section{Table 1-Continued}

\begin{tabular}{|c|c|c|c|c|}
\hline $\begin{array}{l}\text { Estimated Rate of } \\
\text { Follow-up }\end{array}$ & $\begin{array}{l}\text { Age Range at } \\
\text { Baseline }\end{array}$ & $\begin{array}{l}\text { Size of the Cohort } \\
\text { at Baseline }\end{array}$ & $\begin{array}{l}\text { Questions on } \\
\text { Alcohol Intake }\end{array}$ & $\begin{array}{l}\text { Cases of Colorectal } \\
\text { Cancer }\end{array}$ \\
\hline$\%$ & $y$ & $\longleftarrow$ & $n-n$ & $\longrightarrow$ \\
\hline 100 & $40-59$ & 56837 & 3 & 284 \\
\hline 98 & $55-69$ & 34603 & 4 & 796 \\
\hline$>95$ & $55-69$ & 120852 & 6 & 1126 \\
\hline$-^{*}$ & 15-107 & 52913 & 1 & $789 *$ \\
\hline \multirow[t]{2}{*}{98} & $40-76$ & 61463 & 5 & 460 \\
\hline & & 489979 & & 4687 \\
\hline
\end{tabular}


ARTICLE Alcohol Intake and Colorectal Cancer

Table 2. Distribution of Alcohol Intake

\begin{tabular}{|c|c|c|c|c|c|c|c|c|c|}
\hline Study & $\begin{array}{l}\text { Any } \\
\text { Alcohol }\end{array}$ & Beer & Wine & Liquor & Total Alcohol & $\begin{array}{l}\text { Alcohol from } \\
\text { Beer }\end{array}$ & $\begin{array}{l}\text { Alcohol from } \\
\text { Wine }\end{array}$ & $\begin{array}{l}\text { Alcohol from } \\
\text { Liquor }\end{array}$ & $\begin{array}{l}\text { Person-Years } \\
\text { of Alcohol } \\
\text { Intake } \geq 45 \\
\mathrm{~g} / \mathrm{dt}\end{array}$ \\
\hline $\begin{array}{l}\text { Alpha-Tocopherol Beta-Carotene } \\
\text { Cancer Prevention Study }\end{array}$ & 89 & 71 & 21 & 81 & $20.3 \pm 21.8$ & $9.4 \pm 13.9$ & $4.3 \pm 7.6$ & $12.2 \pm 14.2$ & 9.7 \\
\hline $\begin{array}{l}\text { Canadian National Breast } \\
\text { Screening Study }\end{array}$ & 77 & 26 & 67 & 52 & $10.9 \pm 14.5$ & $3.5 \pm 6.2$ & $6.1 \pm 8.8$ & $6.6 \pm 11.5$ & 2.2 \\
\hline lowa Women's Health Study & 45 & 18 & 30 & 26 & $8.7 \pm 12.3$ & $6.5 \pm 11.3$ & $3.0 \pm 4.5$ & $7.1 \pm 10.9$ & 0.9 \\
\hline \multicolumn{10}{|l|}{ Netherlands Cohort Study } \\
\hline Women & 68 & 9 & 65 & 13 & $8.5 \pm 10.6$ & $3.0 \pm 5.0$ & $6.8 \pm 8.6$ & $8.5 \pm 10.4$ & 0.9 \\
\hline Men & 85 & 58 & 51 & 58 & $17.3 \pm 16.7$ & $6.3 \pm 10.0$ & $7.4 \pm 9.7$ & $12.5 \pm 12.9$ & 5.2 \\
\hline \multicolumn{10}{|l|}{ New York State Cohort } \\
\hline Women & 78 & - & - & - & $6.0 \pm 9.4$ & - & - & - & 0.9 \\
\hline Men & 89 & - & - & - & $12.1 \pm 17.1$ & - & - & - & 5.0 \\
\hline Total & & & & & & & & & 2.2 \\
\hline
\end{tabular}

* The percentage of participants who drank beer, wine, and liquor does not add up to the percentage of total drinkers because of overlap of intake.

† Person-years for the Canadian National Breast Screening Study and Netherlands Cohort Study were obtained from the subcohort and cases from outside of the subcohort.

\section{Role of the Funding Source}

The research was funded by the National Institutes of Health and by the National Colorectal Cancer Research Alliance. The funding source had no role in the design, conduct, or reporting of the data.

\section{Results}

Of the 8 studies in this analysis, 2 were conducted among health professionals $(3,11), 3$ were populationbased $(4,5,9), 2$ were conducted in screening programs $(8$, $12)$, and 1 was originally a randomized clinical trial (7) (Table 1). During a maximum of 6 to 16 years of follow-up across the studies, 4687 cases of colorectal cancer were documented, of which 3291 (70\%) were colon cancer, 1628 were proximal colon cancer, and 1410 were distal colon cancer. Across studies, $45 \%$ to $78 \%$ of women and $76 \%$ to $89 \%$ of men consumed alcohol (Table 2). Among drinkers, the mean alcohol intake was 3.5 to 10.9 $\mathrm{g} / \mathrm{d}$ in women and 12.1 to $20.3 \mathrm{~g} / \mathrm{d}$ in men.

We calculated study-specific relative risks for alcohol intake and colorectal cancer, which were subsequently pooled. Total alcohol intake was positively associated with risk for colorectal cancer (Table 3). The elevated risk was limited to alcohol intake of $30 \mathrm{~g} / \mathrm{d}$ or more. The pooled age-adjusted relative risks were 1.21 ( $95 \% \mathrm{CI}, 1.04$ to 1.42) for alcohol intake of 30 to less than $45 \mathrm{~g} / \mathrm{d}$ and 1.51 (CI, 1.25 to 1.83 ) for intake of $45 \mathrm{~g} / \mathrm{d}$ or greater, compared with nondrinkers. The test for heterogeneity among studies was not significant for alcohol consumption of 45 $\mathrm{g} / \mathrm{d}$ or greater $(P>0.2)$, indicating that the differences in relative risks among the cohorts were compatible with random variation. The relative risks were slightly attenuated after adjustment for other potential risk factors for colorec- tal cancer. A significant trend also was observed when nondrinkers were excluded from the analysis $(P<0.001)$.

Because metabolism of alcohol is slower in women than men (35), the association with colorectal cancer may differ by sex. However, results were similar for women and men ( $P$ for heterogeneity due to sex for consumption of 45 $\mathrm{g} / \mathrm{d}$ or greater $>0.2$ ). The positive associations for alcohol intake of $30 \mathrm{~g} / \mathrm{d}$ or greater and colorectal cancer were generally consistent across studies (Figure 1). Additional adjustment for intake of total vitamin $\mathrm{E}$, methionine, fiber, and total fat did not materially change the results (data not shown). Adjustment for age at menarche, menopausal status, parity, and age at first birth did not alter the results among women (data not shown). The findings were similar in analyses that excluded cases diagnosed within the first 4 years of follow-up (data not shown). The pooled relative risks also did not appreciably differ from those obtained when studies were combined into 1 data set (data not shown).

We calculated the population attributable risk, which is the proportion of cases that would be avoided if the risk factor distribution of a high-risk group switched to that of a low-risk group $(36,37)$, by using the age-adjusted relative risk and the prevalence of alcohol intake of $30 \mathrm{~g} / \mathrm{d}$ or greater ( $4 \%$ for women and $13 \%$ for men) from the analysis that combined studies of the same sex into a single data set. The population attributable risk was $0.9 \%$ for women and $5.0 \%$ for men.

The association between alcohol consumption and colorectal cancer risk was slightly J-shaped. We hypothesized that this pattern may have occurred because the reference group of nondrinkers included both never-drinkers and past drinkers, and past drinkers may have an elevated 
Table 3. Pooled Relative Risks for Colorectal Cancer for Categories of Total Alcohol Intake

\begin{tabular}{|c|c|c|c|c|c|c|c|}
\hline \multirow[t]{2}{*}{ Variable } & \multicolumn{6}{|c|}{ Alcohol Intake } & \multirow[t]{2}{*}{$P$ Value* } \\
\hline & $0 \mathrm{~g} / \mathrm{d}$ & $>0$ to $<5 \mathrm{~g} / \mathrm{d}$ & 5 to $<15 \mathrm{~g} / \mathrm{d}$ & 15 to $<30 \mathrm{~g} / \mathrm{d}$ & 30 to $<45 \mathrm{~g} / \mathrm{d}$ & $\geq 45 \mathrm{~g} / \mathrm{d}$ & \\
\hline Median intake, $g / d \dagger$ & 0.0 & 1.9 & 9.4 & 20.8 & 35.6 & 57.1 & \\
\hline Cases of colorectal cancer, $n$ & 1466 & 1475 & 849 & 485 & 244 & 168 & \\
\hline Person-years $\ddagger$ & 1032388 & 1189623 & 645970 & 255990 & 126763 & 71439 & \\
\hline $\begin{array}{l}\text { Age-adjusted relative risk } \\
\quad(95 \% \mathrm{Cl})\end{array}$ & 1.00 & $0.94(0.85-1.03)$ & $0.98(0.89-1.08)$ & $1.04(0.89-1.22)$ & $1.21(1.04-1.42)$ & $1.51(1.25-1.83)$ & $<0.001 \S$ \\
\hline \multicolumn{8}{|l|}{$\begin{array}{l}\text { Multivariate relative risk } \\
\qquad(95 \% \mathrm{Cl}) \|\end{array}$} \\
\hline Overall & 1.00 & $0.94(0.86-1.03)$ & $0.97(0.88-1.06)$ & $1.01(0.86-1.18)$ & $1.16(0.99-1.36)$ & $1.41(1.16-1.72)$ & $<0.001 \S$ \\
\hline Women & 1.00 & $0.96(0.88-1.05)$ & $1.00(0.89-1.13)$ & $0.99(0.78-1.25)$ & $1.19(0.94-1.50)$ & $1.41(0.98-2.02)$ & $0.05 \S$ \\
\hline Men & 1.00 & $0.87(0.63-1.19)$ & $0.90(0.77-1.07)$ & $1.04(0.82-1.31)$ & $1.11(0.86-1.45)$ & $1.41(1.11-1.79)$ & $<0.001 \S$ \\
\hline
\end{tabular}

* Test for trend.

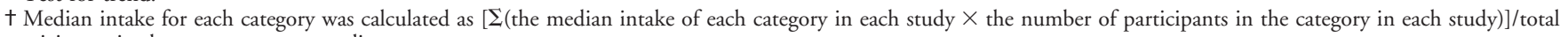
participants in the category across studies.

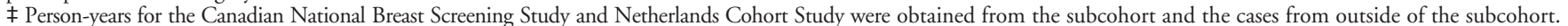
$\S P>0.2$ for between-study heterogeneity for the highest intake category and for between-study heterogeneity due to sex for the highest intake category.

$\|$ Multivariate relative risk was adjusted for smoking (never-smoker, past smoker $<20$ years' duration, past smoker 20 to 39 years' duration, past smoker $\geq 40$ years' duration, current smoker $<25$ cigarettes/d and $<40$ years' duration, current smoker $\geq 25$ cigarettes/d and $<40$ years' duration, current smoker $<25$ cigarettes/d and $\geq 40$ years' duration, or current smoker $\geq 25$ cigarettes/d and $\geq 40$ years' duration), body mass index $\left(<23,23\right.$ to $<25,25$ to $<30$, or $\left.\geq 30 \mathrm{~kg} / \mathrm{m}^{2}\right)$, education (less than high school

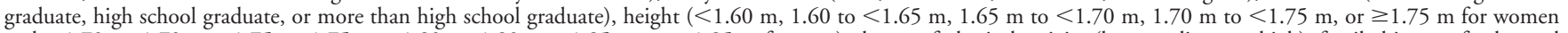
and $<1.70 \mathrm{~m}, 1.70$ to $<1.75 \mathrm{~m}, 1.75$ to $<1.80 \mathrm{~m}, 1.80$ to $<1.85 \mathrm{~m}$, or $\geq 1.85 \mathrm{~m}$ for men), degree of physical activity (low, medium, or high), family history of colorectal

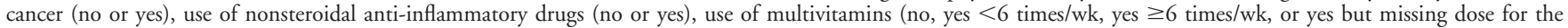

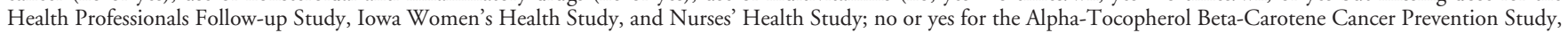
Canadian National Breast Screening Study, Netherlands Cohort Study, and New York State Cohort), energy intake (continuous), red meat intake (quartiles), total milk

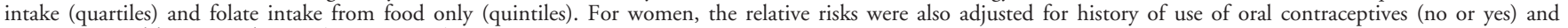
postmenopausal hormone therapy (ever or never).

risk for colorectal cancer $(3,38)$. Information on alcohol consumption during the past 5 to 10 years was available from only 4 studies (proportion of past drinkers among nondrinkers, $5 \%$ to $56 \%$ ). For these studies, compared with nondrinkers (which included never-drinkers and past drinkers), the pooled multivariate relative risks for increasing categories of alcohol intake $(0 \mathrm{~g} / \mathrm{d},>0$ to $<5 \mathrm{~g} / \mathrm{d}, 5$ to $<15 \mathrm{~g} / \mathrm{d}, 15$ to $<30 \mathrm{~g} / \mathrm{d}, 30$ to $<45 \mathrm{~g} / \mathrm{d}$, and $\geq 45 \mathrm{~g} / \mathrm{d}$ )

Figure. Study-specific and pooled multivariate relative risks for colorectal cancer for alcohol intake of $30 \mathrm{~g} / \mathrm{d}$ or greater versus $0 \mathrm{~g} / \mathrm{d}$.

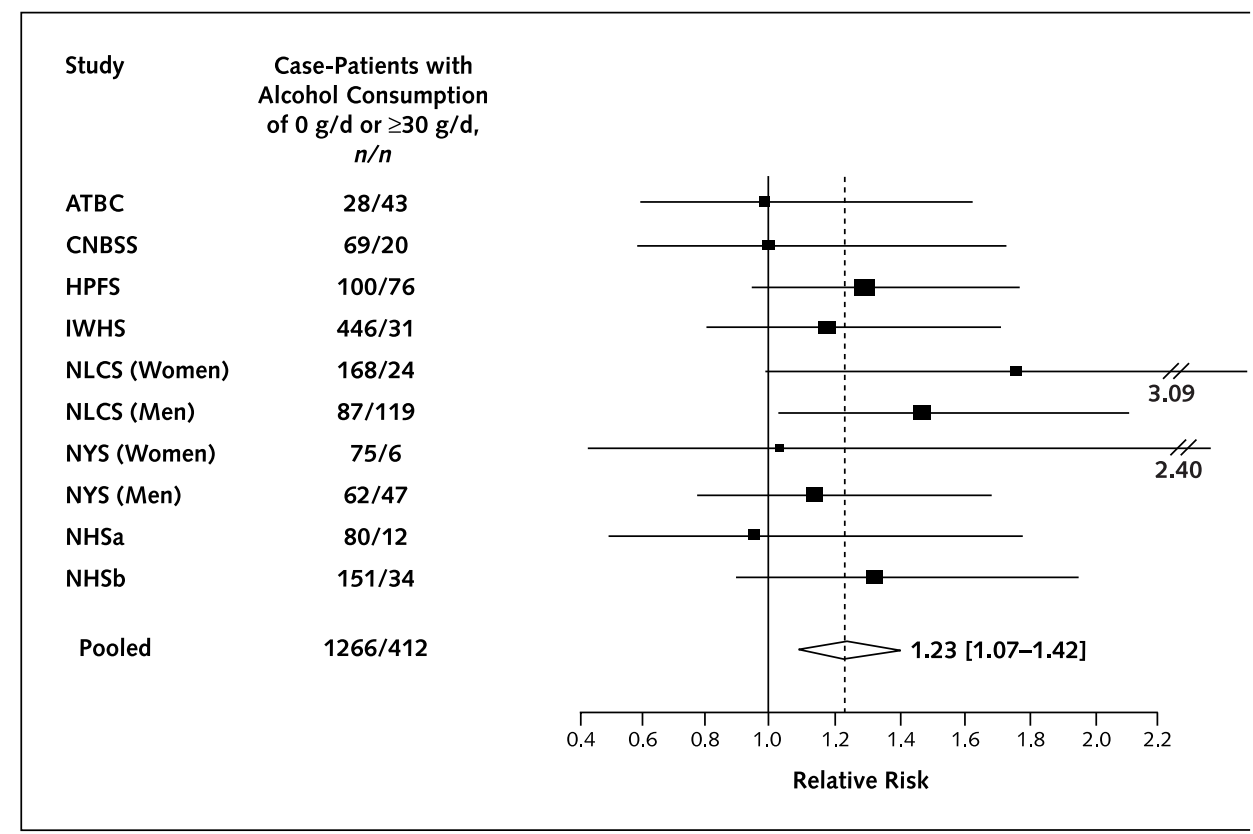

The black squares and horizontal lines show the study-specific relative risks and 95\% CIs. The area of the black squares indicates the study-specific weight in the pooled analysis. The diamond represents the pooled relative risk and 95\% CI. ATBC = Alpha-Tocopherol Beta-Carotene Cancer Prevention Study; CNBSS = Canadian National Breast Screening Study; HPFS = Health Professionals Follow-up Study; IWHS = Iowa Women's Health Study; NLCS $=$ Netherlands Cohort Study; NYS $=$ New York State Cohort; NHS $=$ Nurses' Health Study. The Sweden Mammography Cohort was not included because no patients with colorectal cancer and only 36 persons without colorectal cancer consumed 30 or more g of alcohol daily. $P$ for test for between-study heterogeneity $>0.2$. 
ARTICLE $\mid$ Alcohol Intake and Colorectal Cancer

Table 4. Pooled Relative Risk for Colorectal Cancer for Categories of Alcohol Intakes from Specific Beverages*

\begin{tabular}{|c|c|c|c|c|}
\hline Source of Alcohol & $0 \mathrm{~g} / \mathrm{d}$ & $>0$ to $<30 \mathrm{~g} / \mathrm{d}$ & $\geq 30 \mathrm{~g} / \mathrm{d}$ & $P$ Valuet \\
\hline Cases of colorectal cancer, $n$ & 2612 & 1219 & 67 & \\
\hline Person-years & 1890206 & 1003371 & 47083 & \\
\hline Age-adjusted relative risk $(95 \% \mathrm{Cl})$ & 1.00 & $1.02(0.93-1.12)$ & $1.47(1.13-1.92)$ & $0.06 \ddagger$ \\
\hline Multivariate relative risk $(95 \% \mathrm{Cl}) \S$ & 1.00 & $1.01(0.89-1.13)$ & $1.37(1.00-1.87)$ & $0.2 \ddagger$ \\
\hline Cases of colorectal cancer, $n$ & 2078 & 1768 & 52 & \\
\hline Person-years & 1515247 & 1416395 & 9019 & \\
\hline Age-adjusted relative risk $(95 \% \mathrm{Cl})$ & 1.00 & $0.98(0.90-1.06)$ & $1.74(1.25-2.42)$ & $0.002 \ddagger$ \\
\hline Multivariate relative risk $(95 \% \mathrm{Cl}) \S$ & 1.00 & $0.97(0.89-1.05)$ & $1.82(1.28-2.59)$ & $0.001 \ddagger$ \\
\hline \multicolumn{5}{|l|}{ Liquor } \\
\hline Cases of colorectal cancer, $n$ & 2392 & 1347 & 159 & \\
\hline
\end{tabular}

* The New York State Cohort was not included in the analyses on alcohol from beer, wine, and liquor. Person-years for the Canadian National Breast Screening Study and

Netherlands Cohort Study were obtained from the subcohort and the cases from outside of the subcohort.

+ Test for trend.

$\ddagger P>0.2$ for between-study heterogeneity for the highest intake category and for between-study heterogeneity due to sex for the highest intake category.

$\S$ Multivariate relative risk was adjusted for smoking (never-smoker, past smoker $<20$ years' duration, past smoker 20 to 39 years' duration, past smoker $\geq 40$ years' duration, current smoker $<25$ cigarettes/d and $<40$ years' duration, current smoker $\geq 25$ cigarettes/d and $<40$ years' duration, current smoker $<25$ cigarettes/d and $\geq 40$ years' duration, or current smoker $\geq 25$ cigarettes $/ \mathrm{d}$ and $\geq 40$ years' duration), body mass index $\left(<23,23\right.$ to $<25,25$ to $<30$, or $\left.\geq 30 \mathrm{~kg} / \mathrm{m}^{2}\right)$, education (less than high school graduate, high school graduate, or more than high school graduate), height ( $<1.60 \mathrm{~m}, 1.60$ to $<1.65 \mathrm{~m}, 1.65 \mathrm{~m}$ to $<1.70 \mathrm{~m}, 1.70 \mathrm{~m}$ to $<1.75 \mathrm{~m}$, or $\geq 1.75 \mathrm{~m}$ for women and $<1.70 \mathrm{~m}, 1.70$ to $<1.75 \mathrm{~m}, 1.75$ to $<1.80 \mathrm{~m}, 1.80$ to $<1.85 \mathrm{~m}$, or $\geq 1.85 \mathrm{~m}$ for men), degree of physical activity (low, medium, or high), family history of colorectal cancer (no or yes), use of nonsteroidal anti-inflammatory drugs (no or yes), use of multivitamins (no, yes $<6$ times/wk, yes $\geq 6$ times/wk, or yes but missing dose for the Health Professionals Follow-up Study, Iowa Women's Health Study, and Nurses' Health Study; no or yes for the Alpha-Tocopherol Beta-Carotene Cancer Prevention Study, Canadian National Breast Screening Study, Netherlands Cohort Study, and New York State Cohort), energy intake (continuous), red meat intake (quartiles), total milk

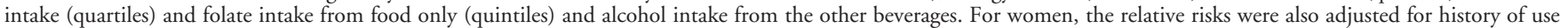
of oral contraceptives (no or yes) and postmenopausal hormone therapy (ever or never).

were $1.00,0.93,0.90,0.98,1.27$, and $1.56(\mathrm{CI}, 1.20$ to $2.04)$, respectively. When past drinkers were excluded from the reference group, the corresponding relative risks changed to $1.00,0.95,0.92,0.99,1.32$, and 1.65 (CI, 1.24 to 2.21 ).

In analyses of each alcoholic beverage, alcohol from beer or wine was significantly associated with an elevated risk for colorectal cancer and alcohol from liquor had a nonsignificant positive association with risk for colorectal cancer (Table 4). The difference among the 3 types of beverage was not statistically significant.

The positive association between alcohol consumption and risk for colorectal cancer was similar across all areas of the large bowel ( $P$ for heterogeneity by subsite for consumption of $45 \mathrm{~g} / \mathrm{d}$ or greater $>0.2$ ) (Table 5 ). We also examined associations between alcohol intake from individual beverages and colon cancer and rectal cancer (Table 6). Although all beverages tended to be more strongly related to rectal than to colon cancer, the differences in relative risks between colon cancer and rectal cancer did not differ significantly.

We examined interactions between alcohol intake and other potential factors related to risk for colorectal cancer (Table 7). The positive association between alcohol intake and colorectal cancer was pronounced among persons with a lower body mass index. The elevated risk among leaner persons was somewhat stronger in men than in women $(P$ for heterogeneity by sex $=0.11$ ). The relative risk for colorectal cancer with an alcohol intake of $30 \mathrm{~g} / \mathrm{d}$ or greater was 1.60 (CI, 1.07 to 2.41 ) for women and 3.51 (CI, 1.45 to 8.50 ) for men with a body mass index less than 22 $\mathrm{kg} / \mathrm{m}^{2}$. These results did not change materially after exclusion of cases that were diagnosed during the first 3 years of follow-up (data not shown).

The association between alcohol use and colorectal cancer did not vary by other factors (Table 7). However, there was a weak suggestion that the positive association between alcohol consumption and risk for colorectal cancer was restricted to persons who did not take multivitamins. In addition, when examined by levels of methionine intake, the positive association was observed only among persons in the 2 lowest tertiles of intake. The association between alcohol consumption and risk for colorectal cancer did not differ by use of hormone replacement therapy (never, past, or current) among postmenopausal women (data not shown).

\section{Discussion}

In this pooled analysis of cohort studies, alcohol consumption was positively associated with risk for colorectal cancer. The relationship was consistent in women and men and across studies. The positive association existed for proximal colon cancer, distal colon cancer, and rectal can- 
Table 5. Pooled Multivariate Relative Risk by Subsite of Colorectal Cancer according to Alcohol Intake*

\begin{tabular}{|c|c|c|c|c|c|c|c|c|}
\hline \multirow[t]{2}{*}{ Subsitet } & \multicolumn{6}{|c|}{ Relative Risk ( $95 \% \mathrm{Cl}$ ) by Alcohol Intake } & \multicolumn{2}{|r|}{$P$ Value $\neq$} \\
\hline & $0 \mathrm{~g} / \mathrm{d}$ & $>0$ to $<5 \mathrm{~g} / \mathrm{d}$ & 5 to $<15 \mathrm{~g} / \mathrm{d}$ & 15 to $<30 \mathrm{~g} / \mathrm{d}$ & 30 to $<45 \mathrm{~g} / \mathrm{d}$ & $\geq 45 \mathrm{~g} / \mathrm{d}$ & $\begin{array}{l}\text { Test for } \\
\text { Trend }\end{array}$ & $\begin{array}{l}\text { Test for Trend, } \\
\text { Excluding Intake } \\
\text { of } 0 \mathrm{~g} / \mathrm{d}\end{array}$ \\
\hline Colon $(n=3291)$ & 1.00 & $0.92(0.84-1.01)$ & $0.94(0.84-1.05)$ & $1.01(0.82-1.24)$ & $1.08(0.89-1.31)$ & $1.45(1.14-1.83)$ & $<0.001$ & 0.001 \\
\hline Proximal colon $(n=1628)$ & 1.00 & $0.90(0.77-1.04)$ & $0.88(0.75-1.04)$ & $0.99(0.80-1.21)$ & $0.98(0.74-1.29)$ & $1.35(0.97-1.89)$ & 0.03 & 0.01 \\
\hline Distal colon $(n=1410)$ & 1.00 & $0.94(0.81-1.09)$ & $1.01(0.85-1.20)$ & $1.02(0.74-1.40)$ & $1.25(0.92-1.68)$ & $1.66(1.17-2.36)$ & 0.04 & 0.01 \\
\hline Rectum $(n=1370)$ & 1.00 & $1.01(0.83-1.22)$ & $0.99(0.82-1.19)$ & $1.05(0.83-1.32)$ & $1.42(1.07-1.88)$ & $1.49(1.04-2.12)$ & 0.006 & 0.02 \\
\hline
\end{tabular}

* Relative risks were adjusted for smoking (never-smoker, past smoker $<20$ years' duration, past smoker 20 to 39 years' duration, past smoker $\geq 40$ years' duration, current

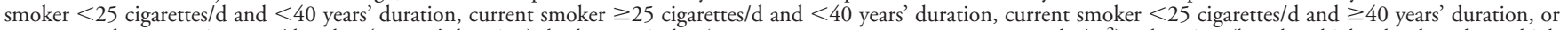

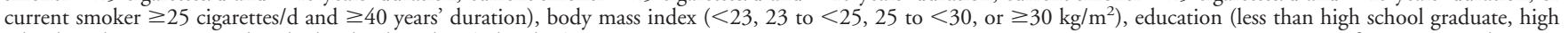
school graduate, or more than high school graduate), height ( $<1.60 \mathrm{~m}, 1.60$ to $<1.65 \mathrm{~m}, 1.65 \mathrm{~m}$ to $<1.70 \mathrm{~m}, 1.70 \mathrm{~m}$ to $<1.75 \mathrm{~m}$, or $\geq 1.75 \mathrm{~m}$ for women and $<1.70$

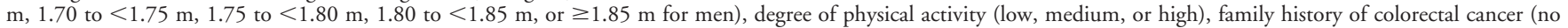

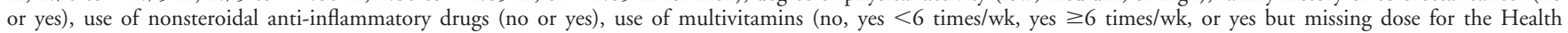
Professionals Follow-up Study, Iowa Women's Health Study, and Nurses' Health Study; no or yes for the Alpha-Tocopherol Beta-Carotene Cancer Prevention Study,

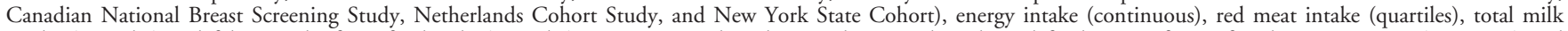

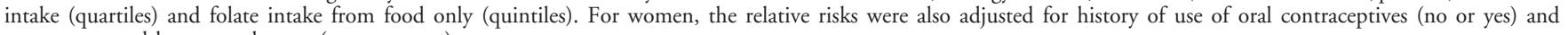
postmenopausal hormone therapy (ever or never).

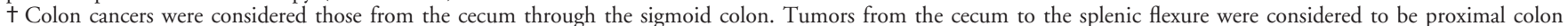
cancer. The remaining tumors in the colon were defined as distal colon cancers. Rectal cancers included tumors in the rectum and the rectosigmoid junction.

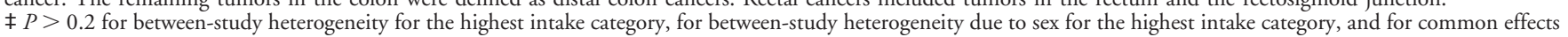
by subsites (proximal colon, distal colon, and rectum) for the highest intake category.

cer. The risk did not differ significantly by type of alcoholic beverage.

Several mechanisms have been suggested for the effect of alcohol on risk for colorectal cancer. First, acetaldehyde, an oxidation product of alcohol, may be responsible for colorectal carcinogenesis $(39,40)$. A recent study reported that high levels of acetaldehyde in rat colon degrade folate, a nutrient that is hypothesized to reduce the risk for colorectal cancer (41). Second, alcohol is an antagonist of methyl-group metabolism and may contribute to abnormal
DNA methylation, an early step in colonic carcinogenesis $(42,43)$. Finally, greater alcohol intake may increase the risk for colorectal cancer indirectly through immune suppression, delay of DNA repair, activation of liver procarcinogens by induction of cytochrome P-450 enzymes, or changes in bile acid composition (44).

Epidemiologic studies on alcohol consumption and colorectal cancer have reported positive or null associations (1). A meta-analysis of 5 cohorts (none of which was included in our analysis) and 22 case-control studies re-

Table 6. Pooled Multivariate Relative Risks by Subsite of Colorectal Cancer according to Intake of Alcohol from Specific Beverages*

\begin{tabular}{|c|c|c|c|c|c|}
\hline \multirow{2}{*}{$\begin{array}{l}\text { Type of Alcohol } \\
\text { and Subsite }\end{array}$} & \multicolumn{3}{|c|}{ Relative Risk ( $95 \% \mathrm{Cl}$ ) by Alcohol Intake } & \multicolumn{2}{|c|}{$P$ Value } \\
\hline & $0 \mathrm{~g} / \mathrm{d}$ & $>0$ to $<15 \mathrm{~g} / \mathrm{d}$ & $\geq 15 \mathrm{~g} / \mathrm{d}$ & Test for Trend & $\begin{array}{l}\text { Test for Common } \\
\text { Effects by Subsite } \\
\text { for the Highest } \\
\text { Intake Category }\end{array}$ \\
\hline \multicolumn{6}{|l|}{ Beer } \\
\hline Colon & 1.00 & $0.96(0.84-1.10)$ & $1.38(1.05-1.82)$ & $0.08+$ & \\
\hline Rectum & 1.00 & $1.05(0.88-1.25)$ & $1.59(1.12-2.25)$ & $0.005 \ddagger$ & $>0.2$ \\
\hline \multicolumn{6}{|l|}{ Wine } \\
\hline Colon & 1.00 & $0.97(0.88-1.07)$ & $1.33(1.00-1.77)$ & $0.03 \S$ & \\
\hline Rectum & 1.00 & $0.96(0.83-1.11)$ & $1.55(1.11-2.17)$ & $0.009+$ & $>0.2$ \\
\hline \multicolumn{6}{|l|}{ Liquor } \\
\hline Colon & 1.00 & $0.99(0.88-1.11)$ & $1.06(0.86-1.30)$ & $>0.2 t$ & \\
\hline Rectum & 1.00 & $0.97(0.81-1.16)$ & $1.10(0.85-1.41)$ & $>0.2 \dagger$ & $>0.2$ \\
\hline
\end{tabular}

* Relative risks were adjusted for smoking (never-smoker, past smoker $<20$ years' duration, past smoker 20 to 39 years' duration, past smoker $\geq 40$ years' duration, current

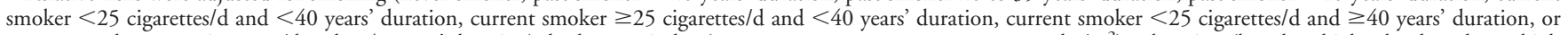

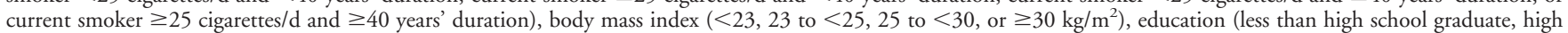
school graduate, or more than high school graduate), height ( $<1.60 \mathrm{~m}, 1.60$ to $<1.65 \mathrm{~m}, 1.65 \mathrm{~m}$ to $<1.70 \mathrm{~m}, 1.70 \mathrm{~m}$ to $<1.75 \mathrm{~m}$, or $\geq 1.75 \mathrm{~m}$ for women and $<1.70$

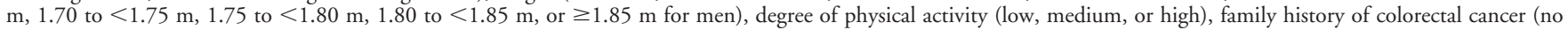

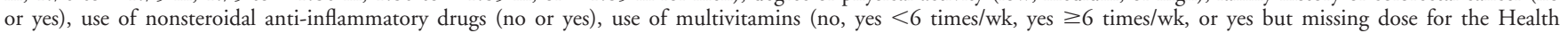

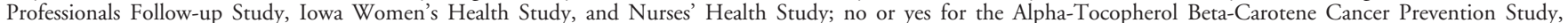

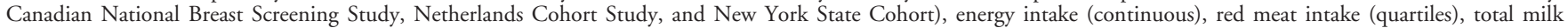

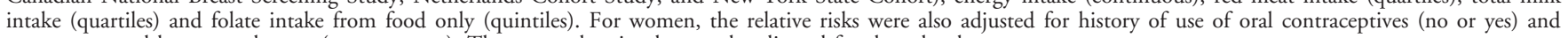
postmenopausal hormone therapy (ever or never). They were also simultaneously adjusted for the other beverages.

$+P>0.2$ for between-study heterogeneity for the highest intake category and for between-study heterogeneity due to sex for the highest intake category.

$\neq P>0.2$ for between-study heterogeneity for the highest intake category and $P=0.17$ for between-study heterogeneity due to sex for the highest intake category.

$\S P>0.2$ for between-study heterogeneity for the highest intake category and $P=0.16$ for between-study heterogeneity due to sex for the highest intake category. 
ARTICLE Alcohol Intake and Colorectal Cancer

Table 7. Pooled Multivariate Relative Risk by Alcohol Intake and Other Risk Factors for Colorectal Cancer*

\begin{tabular}{|c|c|c|c|c|c|c|c|}
\hline Risk Factor & $0 \mathrm{~g} / \mathrm{d}$ & $>0$ to $<5 \mathrm{~g} / \mathrm{d}$ & 5 to $<15 \mathrm{~g} / \mathrm{d}$ & 15 to $<30 \mathrm{~g} / \mathrm{d}$ & $\geq 30 \mathrm{~g} / \mathrm{d}$ & Test for Trend & $\begin{array}{l}\text { Test for Interaction } \\
\text { for Highest Intake } \\
\text { Category }\end{array}$ \\
\hline \multicolumn{8}{|l|}{ Body mass index } \\
\hline$<22 \mathrm{~kg} / \mathrm{m}^{2}(n=663)$ & 1.00 & $1.09(0.87-1.37)$ & $1.28(0.98-1.68)$ & $1.11(0.71-1.72)$ & $1.84(1.27-2.67)$ & $0.003+$ & \\
\hline $22-25 \mathrm{~kg} / \mathrm{m}^{2}(n=1503)$ & 1.00 & $0.85(0.70-1.03)$ & $0.85(0.71-1.01)$ & $0.96(0.76-1.22)$ & $1.23(0.91-1.65)$ & $0.03 \ddagger$ & \\
\hline \multicolumn{8}{|l|}{ Multivitamin use§ } \\
\hline Nonusers $(n=2902)$ & 1.00 & $0.92(0.79-1.07)$ & $0.94(0.83-1.07)$ & $1.01(0.83-1.23)$ & $1.30(1.10-1.54)$ & $<0.001 \ddagger$ & \\
\hline Users $(n=917)$ & 1.00 & $0.96(0.80-1.14)$ & $0.96(0.77-1.20)$ & $0.87(0.65-1.17)$ & $1.06(0.77-1.44)$ & $>0.2 \ddagger$ & $>0.2$ \\
\hline \multicolumn{8}{|l|}{ Total folate intake $\|$} \\
\hline 1st tertile $(n=1063)$ & 1.00 & $0.91(0.75-1.09)$ & $1.01(0.82-1.24)$ & $0.96(0.72-1.28)$ & $1.24(0.96-1.60)$ & $0.07 \ddagger$ & \\
\hline 2nd tertile $(n=1124)$ & 1.00 & $0.89(0.71-1.11)$ & $0.96(0.79-1.18)$ & $1.01(0.78-1.30)$ & $1.16(0.87-1.54)$ & $0.2 \ddagger$ & \\
\hline \multicolumn{8}{|l|}{ Methionine intake } \\
\hline 3rd tertile $(n=1467)$ & 1.00 & $0.93(0.75-1.15)$ & $0.91(0.74-1.11)$ & $1.19(0.84-1.70)$ & $0.88(0.56-1.36)$ & $>0.2^{* *}$ & $>0.2$ \\
\hline \multicolumn{8}{|l|}{ Smoking } \\
\hline Never $(n=1723)+\dagger$ & 1.00 & $0.89(0.79-1.00)$ & $0.92(0.78-1.08)$ & $1.09(0.85-1.39)$ & $1.17(0.84-1.63)$ & $0.19 \neq$ & \\
\hline Past $(n=1549)+\dagger$ & 1.00 & $0.95(0.81-1.13)$ & $0.91(0.76-1.09)$ & $1.08(0.88-1.32)$ & $1.26(1.00-1.58)$ & $0.04 \ddagger$ & \\
\hline Current $(n=904)$ & 1.00 & $1.14(0.86-1.49)$ & $1.14(0.89-1.45)$ & $0.85(0.64-1.12)$ & $1.42(1.11-1.83)$ & $0.007 \ddagger$ & $>0.2$ \\
\hline
\end{tabular}

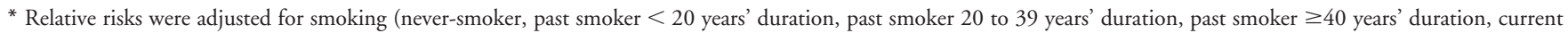

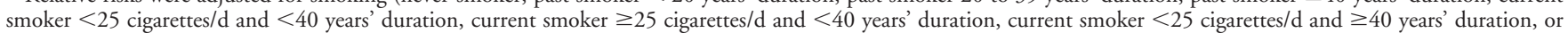
current smoker $\geq 25$ cigarettes/d and $\geq 40$ years' duration), body mass index $\left(<23,23\right.$ to $<25,25$ to $<30$, or $\left.\geq 30 \mathrm{~kg} / \mathrm{m}^{2}\right)$, education (less than high school graduate, high

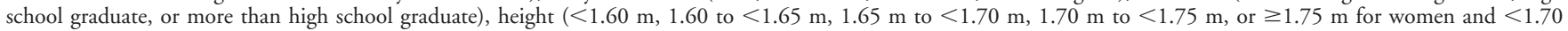

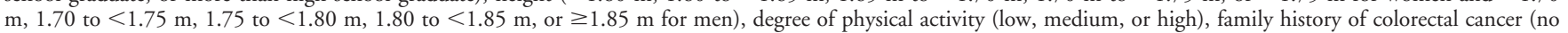
or yes), use of nonsteroidal anti-inflammatory drugs (no or yes), use of multivitamins (no, yes $<6$ times/wk, yes $\geq 6$ times/wk, or yes but missing dose for the Health Professionals Follow-up Study, Iowa Women's Health Study, and Nurses' Health Study; no or yes for the Alpha-Tocopherol Beta-Carotene Cancer Prevention Study,

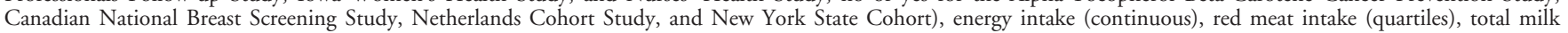

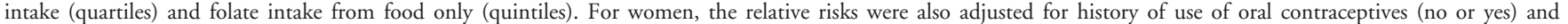
postmenopausal hormone therapy (ever or never).

$+P>0.2$ for between-study heterogeneity for the highest intake category and $P=0.11$ for between-study heterogeneity due to sex for the highest intake category

$\ddagger P>0.2$ for between-study heterogeneity for the highest intake category and for between-study heterogeneity due to sex for the highest intake category.

$\S$ The Canadian National Breast Screening Study and the Sweden Mammography Cohort were not included in this analysis.

$\|$ The Canadian National Breast Screening Study, the Netherlands Cohort Study, and the Sweden Mammography Cohort were not included in this analysis.

П $P=0.14$ for between-study heterogeneity for the highest intake category and $P=0.17$ for between-study heterogeneity due to sex for the highest intake category.

** $P=0.15$ for between-study heterogeneity for the highest intake category and $P>0.2$ for between-study heterogeneity due to sex for the highest intake category.

†† The Alpha-Tocopherol Beta-Carotene Cancer Prevention Study was not included in this analysis.

ported that the relative risks for colorectal cancer in persons who consumed 2 alcoholic beverages daily were 1.32 (CI, 1.16 to 1.51 ) and 1.07 (CI, 1.02 to 1.12 ), respectively (45). Associations were stronger in case-control studies that used population controls than those that used hospital controls (44), possibly because alcohol intake is related to many conditions requiring hospitalization.

In separate analyses of colon cancer and rectal cancer, some (46-57) but not all $(38,58-62)$ studies have reported positive associations between alcohol intake and rectal cancer. The results have been more mixed for colon cancer: Some studies $(38,46,48-50,54,56,57,63,64)$, but not others $(47,52,53,55,58-62,65,66)$, have found a positive association. However, we found that alcohol intake was positively related to both colon cancer and rectal cancer, suggesting that statistical power might have been problematic in previous studies on colon cancer.

Among alcoholic beverages, beer intake has been related to an increased risk for rectal cancer in most $(50-52$,
$55,59,60,67)$ but not all $(46,61,68)$ studies. The association between beer intake and colon cancer has been inconsistent (46, 49, 50, 52, 55, 59, 61, 63, 64, 68, 69). Most studies have reported no association between wine or liquor intake and colon or rectal cancer $(48,50-52,60$, 61, 63, 67-69); however, a few studies have reported positive associations for colon cancer $(46,55,63,64)$. We found that all 3 types of beverage were somewhat positively associated with colorectal cancer and that the risks among these beverages did not differ significantly. We also found a positive association between intake of wine or beer and risk for both colon and rectal cancers. Thus, our data suggest that the positive association between total alcohol and colorectal cancer is attributable to ethanol itself rather than to a specific beverage.

We found that the association between alcohol consumption and risk for colorectal cancer was stronger among persons with a lower body mass index than in those with a higher body mass index. This effect may be related 
to the observation that alcohol intake reduces insulin resistance (70), which is strongly related to obesity (71) and may be related to a higher risk for colorectal cancer (38, $72,73)$. Thus, among persons with a higher body mass index, the adverse effect of alcohol on risk for colorectal cancer might be offset by the beneficial effects of alcohol on insulin resistance. Alternatively, because leaner people have higher blood alcohol concentrations in response to a fixed dose of alcohol, the same biological mechanism may be at work.

The effect of alcohol as an antagonist of methyl-group metabolism may be exacerbated by low levels of folate and methionine, which also contribute to DNA hypomethylation (74). We found that the positive association between alcohol use and risk for colorectal cancer was restricted to persons who did not take multivitamins, a major contributor of folate intake. Multivitamins also contain a more bioavailable form of folate than that in foods $(75,76)$. The positive association between alcohol and colorectal cancer was also not seen in persons who consumed higher amounts of methionine.

We observed a slightly lower risk for colorectal cancer with alcohol intake of 0 to less than $5 \mathrm{~g} / \mathrm{d}$ compared with nondrinkers, perhaps because the reference group of nondrinkers includes past drinkers, who may differ from neverdrinkers (for example, past drinkers may have ceased alcohol intake because of illness). Previous studies have been shown that past drinkers are at higher risk for colorectal cancer than are never-drinkers $(3,38)$. We had information on past alcohol intake from only 4 studies; however, when we excluded past drinkers from the reference group of nondrinkers, the association was slightly stronger. Therefore, including previous drinkers in the reference group is unlikely to account for the positive association overall.

Our study had several strengths. First, we specified a priori that we would include only prospective studies that used a validated food-frequency questionnaire to estimate dietary intake. Prospective studies are less vulnerable to selection and recall biases that may affect case-control studies of associations between diet and disease. These inclusion criteria also minimized sources of variation across studies due to study design or quality. Results in our analyses were consistent across studies. Second, analysis of the primary data from these studies has several advantages compared with conducting a meta-analysis of the published literature. We could create identical categories for alcohol intake and covariates across studies, removing potential sources of heterogeneity that may occur in a metaanalysis of the published literature. Because the studies were selected to evaluate relationships of diet with cancer in general, rather than of alcohol with colorectal cancer, we also minimized the possibility of including only studies that had significant findings (publication bias). In fact, we included 4 studies that have not published data on alcohol and colorectal cancer.
Our study had several limitations. First, we had only one measure of alcohol consumption at baseline and could not investigate lifetime alcohol consumption, alcohol consumption at younger ages, or changes in alcohol consumption during follow-up. Second, we could not examine drinking patterns or duration of alcohol use. Third, some of the studies did not measure some risk factors for colorectal neoplasia. However, the pooled multivariate results were similar to the age-adjusted results, indicating that this deficiency was not important. Fourth, we did not have information on screening for colorectal cancer. However, during the follow-up period of most of the samples, screening endoscopy and polyp removal were not widespread. Finally, measurement error on alcohol intake may bias the results. However, validation data in our studies have generally supported that alcohol intake was well measured (16, $17,19)$ (Wolk A. Personal communication).

Two of the studies also reported strong correlations between alcohol intake and serum high-density lipoprotein cholesterol, a biomarker that cannot be affected by biased reporting (19). Measurement error in other covariates, including dietary covariates, may be a concern. However, because the age-adjusted results were similar to the multivariate results, the influence of measurement error in covariates should be minimal.

In summary, a single determination of alcohol intake was associated with a modest relative elevation in risk for colorectal cancer, mainly for intake of $30 \mathrm{~g} / \mathrm{d}$ or greater, a level of intake reported by $4 \%$ of women and $13 \%$ of men. Whether this association is causal depends in part on whether participants in the higher intake groups differ from the other participants in some unmeasured determinants of risk for colorectal cancer, or whether the potential confounding factors for which we adjusted were measured with lesser accuracy in this subset. The associations were consistent across studies, between men and women, and across subsites of the large bowel. Although moderate alcohol consumption has been associated with a reduced risk for cardiovascular disease, alcohol intake has been positively associated with risk for cancers at several sites, including the large bowel. Both the risks and benefits of alcohol intake should be considered in decisions about drinking.

From Channing Laboratory, Brigham and Women's Hospital, Harvard Medical School, Harvard School of Public Health, and Harvard Center for Cancer Prevention, Boston, Massachusetts; Maastricht University, Maastricht, and TNO Nutrition and Food Research Institute, Zeist, the Netherlands; University of Minnesota, Minneapolis, Minnesota; State University of New York, Buffalo, and Albert Einstein College of Medicine, Bronx, New York; Regional Oncologic Center, Uppsala, and National Institute of Environmental Medicine, Stockholm, Sweden; College of Medicine, Hallym University, Chunchon, South Korea; Finnish Cancer Registry and National Public Health Institute, Helsinki, Finland; Faculty of Medicine, University of Toronto, Toronto, Ontario, Canada; and H. Lee Moffitt Cancer Center and Research Institute, Tampa, Florida. 
ARTICLE Alcohol Intake and Colorectal Cancer

Acknowledgments: The authors thank Shiaw-Shyuan Yaun for assistance with data analysis.

Grant Support: By research grants CA55075 and CA78548 from the National Institutes of Health and by the National Colorectal Cancer Research Alliance.

Potential Financial Conflicts of Interest: None disclosed.

Requests for Single Reprints: Eunyoung Cho, $\mathrm{ScD}$, Channing Laboratory, Department of Medicine, Brigham and Women's Hospital and Harvard Medical School, 181 Longwood Avenue, Boston, MA 02115; e-mail, eunyoung.cho@channing.harvard.edu.

Current author addresses and author contributions are available at www .annals.org.

\section{References}

1. World Cancer Research Fund, American Institute for Cancer Research. Food, Nutrition and the Prevention of Cancer: A Global Perspective. Washington, DC: American Institutue for Cancer Research; 1997.

2. Glynn SA, Albanes D, Pietinen P, Brown CC, Rautalahti M, Tangrea JA, et al. Alcohol consumption and risk of colorectal cancer in a cohort of Finnish men. Cancer Causes Control. 1996;7:214-23. [PMID: 8740734]

3. Giovannucci E, Rimm EB, Ascherio A, Stampfer MJ, Colditz GA, Willett WC. Alcohol, low-methionine-low-folate diets, and risk of colon cancer in men. J Natl Cancer Inst. 1995;87:265-73. [PMID: 7707417]

4. Gapstur SM, Potter JD, Folsom AR. Alcohol consumption and colon and rectal cancer in postmenopausal women. Int J Epidemiol. 1994;23:50-7. [PMID: 8194924]

5. Goldbohm RA, Van den Brandt PA, Van 't Veer P, Dorant E, Sturmans F, Hermus RJ. Prospective study on alcohol consumption and the risk of cancer of the colon and rectum in the Netherlands. Cancer Causes Control. 1994;5:95104. [PMID: 8167268]

6. Hunter DJ, Spiegelman D, Adami HO, Beeson L, van den Brandt PA, Folsom AR, et al. Cohort studies of fat intake and the risk of breast cancer-a pooled analysis. N Engl J Med. 1996;334:356-61. [PMID: 8538706]

7. The alpha-tocopherol, beta-carotene lung cancer prevention study: design, methods, participant characteristics, and compliance. The ATBC Cancer Prevention Study Group. Ann Epidemiol. 1994;4:1-10. [PMID: 8205268]

8. Terry P, Jain M, Miller AB, Howe GR, Rohan TE. Dietary intake of folic acid and colorectal cancer risk in a cohort of women. Int J Cancer. 2002;97: 864-7. [PMID: 11857369]

9. Bandera EV, Freudenheim JL, Marshall JR, Zielezny M, Priore RL, Brasure $\mathrm{J}$, et al. Diet and alcohol consumption and lung cancer risk in the New York State Cohort (United States). Cancer Causes Control. 1997;8:828-40. [PMID: 9427425]

10. Bandera EV, Freudenheim JL, Marshall JR, et al. Impact of losses to follow-up on diet/alcohol and lung cancer analyses in the New York State Cohort. Nutr Cancer. 2002;42:41-7. [PMID: 12235649]

11. Martinez ME, Giovannucci EL, Colditz GA, et al. Calcium, vitamin D, and the occurrence of colorectal cancer among women. J Natl Cancer Inst. 1996;88: 1375-82. [PMID: 8827015]

12. Terry P, Wolk A. Tea consumption and the risk of colorectal cancer in Sweden. Nutr Cancer. 2001;39:176-9. [PMID: 11759277]

13. Pietinen P, Hartman AM, Haapa E, Rasanen L, Haapakoski J, Palmgren J, et al. Reproducibility and validity of dietary assessment instruments. II. A qualitative food frequency questionnaire. Am J Epidemiol. 1988;128:667-76. [PMID: 2843041]

14. Jain M, Howe GR, Rohan T. Dietary assessment in epidemiology: comparison on food frequency and a diet history questionnaire with a 7-day food record. Am J Epidemiol. 1996;143:953-60. [PMID: 8610709]

15. Rimm EB, Giovannucci EL, Stampfer MJ, Colditz GA, Litin LB, Willett WC. Reproducibility and validity of an expanded self-administered semiquanti- tative food frequency questionnaire among male health professionals. Am J Epidemiol. 1992;135:1114-26. [PMID: 1632423]

16. Munger RG, Folsom AR, Kushi LH, Kaye SA, Sellers TA. Dietary assessment of older Iowa women with a food frequency questionnaire: nutrient intake, reproducibility, and comparison with 24-hour dietary recall interviews. Am J Epidemiol. 1992;136:192-200. [PMID: 1415141]

17. Goldbohm RA, van den Brandt PA, Brants HA, van't Veer P, Al M, Sturmans F, et al. Validation of a dietary questionnaire used in a large-scale prospective cohort study on diet and cancer. Eur J Clin Nutr. 1994;48:253-65. [PMID: 8039485]

18. Feskanich D, Marshall J, Rimm EB, Litin LB, Willett WC. Simulated validation of a brief food frequency questionnaire. Ann Epidemiol. 1994;4:181-7. [PMID: 8055118]

19. Giovannucci E, Colditz G, Stampfer MJ, Rimm EB, Litin L, Sampson L, et al. The assessment of alcohol consumption by a simple self-administered questionnaire. Am J Epidemiol. 1991;133:810-7. [PMID: 2021148]

20. Rothman KJ, Greenland S. Modern Epidemiology. 2nd ed. Philadelphia: Lippincott-Raven; 1998.

21. Bostick RM, Potter JD, Sellers TA, McKenzie DR, Kushi LH, Folsom AR. Relation of calcium, vitamin D, and dairy food intake to incidence of colon cancer among older women. The Iowa Women's Health Study. Am J Epidemiol. 1993;137:1302-17. [PMID: 8333412]

22. Kampman E, Goldbohm RA, van den Brandt PA, van 't Veer P. Fermented dairy products, calcium, and colorectal cancer in The Netherlands Cohort Study. Cancer Res. 1994;54:3186-90. [PMID: 8205538]

23. Graham S, Zielezny M, Marshall J, Priore R, Freudenheim J, Brasure J, et al. Diet in the epidemiology of postmenopausal breast cancer in the New York State Cohort. Am J Epidemiol. 1992;136:1327-37. [PMID: 1336931]

24. Terry P, Baron JA, Bergkvist L, Holmberg L, Wolk A. Dietary calcium and vitamin D intake and risk of colorectal cancer: a prospective cohort study in women. Nutr Cancer. 2002;43:39-46. [PMID: 12467133]

25. Pietinen P, Malila N, Virtanen M, Hartman TJ, Tangrea JA, Albanes D, et al. Diet and risk of colorectal cancer in a cohort of Finnish men. Cancer Causes Control. 1999;10:387-96. [PMID: 10530608]

26. U.S. Department of Agriculture. USDA Nutrient Database for Standard Reference, Release 12. Washington, DC: U.S. Department of Agriculture, Agricultural Research Service; 1998.

27. SAS/STAT Software. The PHREG Procedure. Preliminary Documentation. Cary, NC: SAS Institute; 1991.

28. Prentice RL. A case-cohort design for epidemiologic cohort studies and disease prevention trials. Biometrika. 1986;73:1-12.

29. EPICURE User's Guide: The PEANUTS Program. Seattle: Microsoft; 1993. 30. DerSimonian R, Laird N. Meta-analysis in clinical trials. Control Clin Trials. 1986;7:177-88. [PMID: 3802833]

31. Cochran WG. The combination of estimates from different experiments. Biometrics. 1954;10:101-29.

32. Anderson TW. An Introduction to Multivariate Statistical Analysis. 2nd ed. New York: Wiley; 1988.

33. Stram DO. Meta-analysis of published data using a linear mixed-effects model. Biometrics. 1996;52:536-44. [PMID: 8672702]

34. Prentice RL, Kalbfleisch JD, Peterson AV Jr, Flournoy N, Farewell VT, Breslow NE. The analysis of failure times in the presence of competing risks. Biometrics. 1978;34:541-54. [PMID: 373811]

35. Frezza M, di Padova C, Pozzato G, Terpin M, Baraona E, Lieber CS. High blood alcohol levels in women. The role of decreased gastric alcohol dehydrogenase activity and first-pass metabolism. N Engl J Med. 1990;322:95-9. [PMID: 2248624]

36. Bruzzi P, Green SB, Byar DP, Brinton LA, Schairer C. Estimating the population attributable risk for multiple risk factors using case-control data. Am J Epidemiol. 1985;122:904-14. [PMID: 4050778]

37. Rockhill B, Weinberg CR, Newman B. Population attributable fraction estimation for established breast cancer risk factors: considering the issues of high prevalence and unmodifiability. Am J Epidemiol. 1998;147:826-33. [PMID: 9583712]

38. Le Marchand L, Wilkens LR, Kolonel LN, Hankin JH, Lyu LC. Associations of sedentary lifestyle, obesity, smoking, alcohol use, and diabetes with the risk of colorectal cancer. Cancer Res. 1997;57:4787-94. [PMID: 9354440] 
39. Seitz HK, Simanowski UA, Garzon FT, Rideout JM, Peters TJ, Koch A, et al. Possible role of acetaldehyde in ethanol-related rectal cocarcinogenesis in the rat. Gastroenterology. 1990;98:406-13. [PMID: 2295396]

40. Salaspuro M. Bacteriocolonic pathway for ethanol oxidation: characteristics and implications. Ann Med. 1996;28:195-200. [PMID: 8811162]

41. Homann N, Tillonen J, Salaspuro M. Microbially produced acetaldehyde from ethanol may increase the risk of colon cancer via folate deficiency. Int J Cancer. 2000;86:169-73. [PMID: 10738242]

42. Fearon ER, Vogelstein B. A genetic model for colorectal tumorigenesis. Cell. 1990;61:759-67. [PMID: 2188735]

43. Choi SW, Stickel F, Baik HW, Kim YI, Seitz HK, Mason JB. Chronic alcohol consumption induces genomic but not $\mathrm{p} 53$-specific DNA hypomethylation in rat colon. J Nutr. 1999;129:1945-50. [PMID: 10539767]

44. Kune GA, Vitetta L. Alcohol consumption and the etiology of colorectal cancer: a review of the scientific evidence from 1957 to 1991. Nutr Cancer. 1992;18:97-111. [PMID: 1437657]

45. Longnecker MP, Orza MJ, Adams ME, Vioque J, Chalmers TC. A metaanalysis of alcoholic beverage consumption in relation to risk of colorectal cancer. Cancer Causes Control. 1990;1:59-68. [PMID: 2151680]

46. Williams RR, Horm JW. Association of cancer sites with tobacco and alcohol consumption and socioeconomic status of patients: interview study from the Third National Cancer Survey. J Natl Cancer Inst. 1977;58:525-47. [PMID: 557114]

47. Pollack ES, Nomura AM, Heilbrun LK, Stemmermann GN, Green SB. Prospective study of alcohol consumption and cancer. N Engl J Med. 1984;310: 617-21. [PMID: 6694673]

48. Klatsky AL, Armstrong MA, Friedman GD, Hiatt RA. The relations of alcoholic beverage use to colon and rectal cancer. Am J Epidemiol. 1988;128: 1007-15. [PMID: 3189277]

49. Hirayama T. Association between alcohol consumption and cancer of the sigmoid colon: observations from a Japanese cohort study. Lancet. 1989;2:725-7. [PMID: 2570969]

50. Longnecker MP. A case-control study of alcoholic beverage consumption in relation to risk of cancer of the right colon and rectum in men. Cancer Causes Control. 1990;1:5-14. [PMID: 2102276]

51. Freudenheim JL, Graham S, Marshall JR, Haughey BP, Wilkinson G. Lifetime alcohol intake and risk of rectal cancer in western New York. Nutr Cancer. 1990;13:101-9. [PMID: 2300490]

52. Stemmermann GN, Nomura AM, Chyou PH, Yoshizawa C. Prospective study of alcohol intake and large bowel cancer. Dig Dis Sci. 1990;35:1414-20. [PMID: 2226103]

53. Choi SY, Kahyo H. Effect of cigarette smoking and alcohol consumption in the etiology of cancers of the digestive tract. Int J Cancer. 1991;49:381-6. [PMID: 1917136]

54. Hu JF, Liu YY, Yu YK, Zhao TZ, Liu SD, Wang QQ. Diet and cancer of the colon and rectum: a case-control study in China. Int J Epidemiol. 1991;20: 362-7. [PMID: 1917235]

55. Newcomb PA, Storer BE, Marcus PM. Cancer of the large bowel in women in relation to alcohol consumption: a case-control study in Wisconsin (United States). Cancer Causes Control. 1993;4:405-11. [PMID: 8218871]

56. Chyou PH, Nomura AM, Stemmermann GN. A prospective study of colon and rectal cancer among Hawaii Japanese men. Ann Epidemiol. 1996;6:276-82. [PMID: 8876837]

57. Murata M, Tagawa M, Watanabe S, Kimura H, Takeshita T, Morimoto K. Genotype difference of aldehyde dehydrogenase 2 gene in alcohol drinkers influences the incidence of Japanese colorectal cancer patients. Jpn J Cancer Res. 1999;90:711-9. [PMID: 10470282]

58. Tuyns AJ, Pequignot G, Gignoux M, Valla A. Cancers of the digestive tract, alcohol and tobacco. Int J Cancer. 1982;30:9-11. [PMID: 7118300]

59. Miller AB, Howe GR, Jain M, Craib KJ, Harrison L. Food items and food groups as risk factors in a case-control study of diet and colo-rectal cancer. Int J Cancer. 1983;32:155-61. [PMID: 6307893]

60. Kune S, Kune GA, Watson LF. Case-control study of alcoholic beverages as etiological factors: the Melbourne Colorectal Cancer Study. Nutr Cancer. 1987; 9:43-56. [PMID: 3808969]

61. Peters RK, Garabrant DH, Yu MC, Mack TM. A case-control study of occupational and dietary factors in colorectal cancer in young men by subsite. Cancer Res. 1989;49:5459-68. [PMID: 2766308]

62. Ferraroni M, Negri E, La Vecchia C, D’Avanzo B, Franceschi S. Socioeconomic indicators, tobacco and alcohol in the aetiology of digestive tract neoplasms. Int J Epidemiol. 1989;18:556-62. [PMID: 2807657]

63. Peters RK, Pike MC, Garabrant D, Mack TM. Diet and colon cancer in Los Angeles County, California. Cancer Causes Control. 1992;3:457-73. [PMID: 1525327]

64. Meyer F, White E. Alcohol and nutrients in relation to colon cancer in middle-aged adults. Am J Epidemiol. 1993;138:225-36. [PMID: 8395140]

65. Slattery ML, West DW, Robison LM, French TK, Ford MH, Schuman $\mathrm{KL}$, et al. Tobacco, alcohol, coffee, and caffeine as risk factors for colon cancer in a low-risk population. Epidemiology. 1990;1:141-5. [PMID: 2073501]

66. Slattery ML, Schaffer D, Edwards SL, Ma KN, Potter JD. Are dietary factors involved in DNA methylation associated with colon cancer? Nutr Cancer. 1997;28:52-62. [PMID: 9200151]

67. Kabat GC, Howson CP, Wynder EL. Beer consumption and rectal cancer. Int J Epidemiol. 1986;15:494-501. [PMID: 3818156]

68. Bidoli E, Franceschi S, Talamini R, Barra S, La Vecchia C. Food consumption and cancer of the colon and rectum in north-eastern Italy. Int J Cancer. 1992;50:223-9. [PMID: 1730516]

69. Pickle LW, Greene MH, Ziegler RG, Toledo A, Hoover R, Lynch HT, et al. Colorectal cancer in rural Nebraska. Cancer Res. 1984;44:363-9. [PMID: 6690049]

70. Facchini F, Chen YD, Reaven GM. Light-to-moderate alcohol intake is associated with enhanced insulin sensitivity. Diabetes Care. 1994;17:115-9. [PMID: 7907975]

71. Colditz GA, Willett WC, Stampfer MJ, Manson JE, Hennekens CH, Arky $\mathrm{RA}$, et al. Weight as a risk factor for clinical diabetes in women. Am J Epidemiol. 1990;132:501-13. [PMID: 2389754]

72. La Vecchia C, Negri E, Decarli A, Franceschi S. Diabetes mellitus and colorectal cancer risk. Cancer Epidemiol Biomarkers Prev. 1997;6:1007-10. [PMID: 9419395]

73. Hu FB, Manson JE, Liu S, Hunter D, Colditz GA, Michels KB, et al. Prospective study of adult onset diabetes mellitus (type 2) and risk of colorectal cancer in women. J Natl Cancer Inst. 1999;91:542-7. [PMID: 10088625]

74. Fenech $\mathrm{M}$. The role of folic acid and vitamin $\mathrm{B}_{12}$ in genomic stability of human cells. Mutat Res. 2001;475:57-67. [PMID: 11295154]

75. Herbert V. Recommended dietary intakes (RDI) of folate in humans. Am J Clin Nutr. 1987;45:661-70. [PMID: 3565292]

76. Gregory JF 3rd. Bioavailability of folate. Eur J Clin Nutr. 1997;51 Suppl 1:S54-9. [PMID: 9023482] 
Current Author Addresses: Drs. Cho, Colditz, Giovannucci, Speizer, Willett, and Hunter: Channing Laboratory, 181 Longwood Avenue, Boston, MA 02115.

Drs. Smith-Warner and Ritz: Harvard School of Public Health, 665 Huntington Avenue, Boston, MA 02115.

Dr. van den Brandt: Department of Epidemiology, Universiteit Maastricht, PO Box 616 NL-6200 MD Maastricht, the Netherlands.

Dr. Folsom: Division of Epidemiology, University of Minnesota, School of Public Health, Suite 300, 1300 Second Street, Minneapolis, MN 55454-1015.

Drs. Freudenheim and Graham: Department of Social and Preventive Medicine, State University of New York at Buffalo, 270 Farber Hall, 3435 Main Street, Buffalo, NY 14214-3000.

Dr. Goldbohm: Department of Epidemiology, TNO Nutrition and Food Research Institute, Ultrechtseweg 48, PO Box 360, 3700 AJ Zeist, the Netherlands.

Dr. Holmberg: Regional Oncologic Centre, SE-751 85 Uppsala, Sweden.

Dr. Kim: Department of Social and Preventive Medicine, Hallym, University College of Medicine, 1 Okchon-dong, Chunchon, Kangwon-do 200-702, South Korea.

Dr. Malila: Finnish Cancer Registry, Liisankatu 21 B, 00170 Helsinki, Finland.

Dr. Miller: Department of Preventive Medicine and Biostatistics, Faculty of Medicine, University of Toronto, 1 King's College Circle, Toronto, Ontario M5S 1A6, Canada.

Dr. Pietinen: Department of Epidemiology and Health Promotion, National Public Health Institute, Mannerheimintie 166, FIN-00300 Helsinki, Finland.

Dr. Rohan: Department of Epidemiology and Population Health, Albert Einstein College of Medicine, 1300 Morris Park Avenue, Bronx, NY 10461.
Dr. Sellers: H. Lee Moffitt Cancer Center and Research Institute at the University of South Florida, 12902 Magnolia Drive, Tampa, FL 33612. Dr. Wolk: Division of Nutritional Epidemiology, National Institute of Environmental Medicine, Karolinska Institute, S-171 77 Stockholm, Sweden.

Author Contributions: Conception and design: E. Cho, A. Wolk, E. Giovannucci, W. Willett, P.A. van den Brandt, R.A. Goldbohm, D. Hunter.

Analysis and interpretation of the data: E. Cho, T.E. Rohan, E. Giovannucci, J. Ritz, W. Willett, J.L. Freudenheim, P.A. van den Brandt, D. Hunter, D.-H. Kim, L. Holmberg.

Drafting of the article: E. Cho, T.E. Rohan, D.-H. Kim.

Critical revision of the article for important intellectual content: S. Smith-Warner, T.E. Rohan, A. Wolk, T.A. Sellers, A.R. Folsom, E. Giovannucci, J. Ritz, W. Willett, P.A. van den Brandt, R.A. Goldbohm, P. Pietinen, N. Malila, D. Hunter, A.B. Miller, L. Holmberg.

Final approval of the article: S. Smith-Warner, T.E. Rohan, A. Wolk, G.A. Colditz, A.R. Folsom, E. Giovannucci, J. Ritz, W. Willett, J.L. Freudenheim, P.A. van den Brandt, R.A. Goldbohm, P. Pietinen, N. Malila, D. Hunter, D.-H. Kim, A.B. Miller, L. Holmberg.

Provision of study materials or patients: T.E. Rohan, A. Wolk, A.R. Folsom, E. Giovannucci, J.L. Freudenheim, P.A. van den Brandt, R.A. Goldbohm, D. Hunter, A.B. Miller, L. Holmberg.

Statistical expertise: G.A. Colditz, J. Ritz, W. Willett.

Obtaining of funding: A. Wolk, T.A. Sellers, E. Giovannucci, W. Willett, R.A. Goldbohm, D. Hunter.

Administrative, technical, or logistic support: G.A. Colditz, W. Willett, L. Holmberg.

Collection and assembly of data: E. Cho, S. Smith-Warner, T.A. Sellers, E. Giovannucci, J.L. Freudenheim, P.A. van den Brandt, R.A. Goldbohm, P. Pietinen, N. Malila, D. Hunter, L. Holmberg. 